\title{
Combined assessment of climate change and socio-economic development as drivers of freshwater availability in the South of Portugal
}

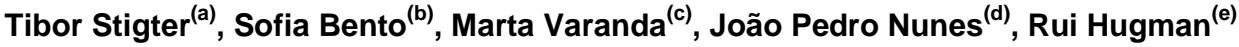 \\ (a) Geo-Systems Centre/CVRM, Instituto \\ Superior Técnico, Universidade Técnica de \\ Lisboa, Lisbon, tibor.stigter@ist.utl.pt \\ (d) CESAM \& Department of Environment \\ and Planning, Universidade de Aveiro, \\ Aveiro, ipcn@ua.pt \\ (b) SOCIUS/Instituto Superior de Economia \\ e Gestão, Universidade Técnica de Lisboa, \\ Lisbon, sbento@iseg.utl.pt \\ (e) Geo-Systems Centre/CVRM, \\ Universidade do Algarve, Faro, \\ ruitwohigh@yahoo.com
}

(c) Instituto de Ciências Sociais, Universidade de Lisboa, Lisbon, marta.varanda@ics.ul.pt

\begin{abstract}
A combined assessment of the potential impacts from climate change (CC) and socio-economic development (SED) on water resources is presented for a large aquifer in the south of Portugal, under large pressures from water consuming and contaminating activities. We aim to understand how this may further be aggravated by $\mathrm{CC}$ and SED, particularly for agriculture, the largest water consumer in the region. Short-term (2020-2050) and long-term (2070-2100) CC scenarios were developed and used to build aquifer recharge and crop water demand scenarios, using different models and methods to account for uncertainty. SED scenarios were developed using a number of techniques, and discussed at workshops with farmers and institutional stakeholders in the water sector. Groundwater use was quantified for each scenario and then integrated with the CC scenarios. They were run through a calibrated groundwater flow model, to study their individual and joint impacts on water levels and discharge rates into the bordering coastal estuary where relevant freshwater dependent wetlands exist. Recharge scenarios show clearly negative long-term trends, but high uncertainties in the short-term. Scenario SED1 predicting intensification and decline of small farms, considered by stakeholders to be most likely, shows a large drop in agricultural area and water demand. SED2, the most desired scenario, foresees growth and modernization of agriculture, but could be unsustainable in combination with CC. The joint analysis of CC and SED revealed to be challenging but useful. It involved the use of different methods across the border between natural and social sciences, aiming to contribute to transdisciplinary water management.
\end{abstract}

KEY WORDS: Climate change, socio-economic development, scenarios for water resources, South Portugal.

\section{INTRODUCTION}

Similar to other Mediterranean regions, freshwater availability in the south of Portugal is under increasing pressures from water consuming and contaminating activities. This threatens drinking water and irrigation supplies as well as the sustainability of wetlands that constitute groundwater dependent ecosystems (GDEs). In coastal aquifers overexploitation can lead to seawater intrusion. Climate change (CC) may aggravate such problems, particularly in the Mediterranean region (e.g. Giorgi, 2006), due to the combined effect of rising sea levels, increased water demand due to global warming, and reduced aquifer recharge. Groundwater researchers have therefore started to integrate CC scenarios into their studies. These particularly try to predict the impact of changes in aquifer recharge on groundwater levels and discharge rates (e.g. Brouyère et al. 2004; Candela et al. 2009; Jackson et al. 2011), and can also integrate sea level rise and water demand scenarios (Stigter et al., in press).

Such studies, undoubtedly pertinent, generally ignore future changes in socio-economic development (SED) and the possible impacts this can have on freshwater supplies and demand. This is because SED scenarios are difficult to predict and have important feedback relationships with CC, particularly on a global scale (Nakićenović \& Swart, 2000). In addition, the time frames for SED and CC scenario analysis are quite different. Climate modellers prefer discussing the future 100 years from now, whereas socioeconomic researchers using participated foresight methodologies, are mainly concerned with what happens in the following two to three decades, as looking further ahead inhibits the motivation and engagement of stakeholders (Roncoli, 2006). Climate change may not even be a key issue for actors in the economy and governance of regional territories (Faysse et al., 2012). Finally, the combination of SED and CC scenarios involves the participation of disciplines from the natural and social sciences and a combination of methods, qualitative and quantitative, in a truly collaborative endeavour that encounters many difficulties (Varanda \& Bento, 2012). According to the UNESCO (2010) the scarcity of research engaging both the natural and the social sciences is leading to a deficient understanding of global changes affecting human societies.

Regional integrated studies of the expected evolution of SED and CC are essential in order to assess the individual and combined pressure they might exert on freshwater resources in the near and more distant future. Here such scenarios were developed for the largest aquifer system in the south of Portugal, Querença-Silves, in the scope of two transnational projects. Short-term (2020-2050) and longterm (2070-2100) CC scenarios were developed for the study site and used to build aquifer recharge scenarios based on soil water balance calculation methods. SED scenarios were developed and then presented in workshops to the farmers and to other stakeholders, including the Water Basin Authority and the Regional Agricultural Administration, among others, in order to support a reflection over alternatives for development of the region. For each scenario the evolution of water consumption was evaluated. The potential individual and joint effects of CC and SED on the quantitative status of the aquifer was 
illustrated by integrating several scenarios in a calibrated groundwater flow model of the aquifer.

\section{METHODS}

\section{Study area}

The large Querença-Silves aquifer is built up of karstified carbonate rock, covering an E-W elongated area of $318 \mathrm{~km}^{2}$ (Figure 1). It is the most important groundwater reservoir in South Portugal. Surface-groundwater ecotones occur at the many springs that characterize the system. Groundwater flows mainly towards the south and west, where it discharges into the Arade estuary (Figure 1), largely through (partly subestuarine) springs that feed freshwater dependent wetlands. Land use is dominated by irrigated citrus culture in the west and extensive dry farming (olive, carob, almond and fig trees) in the eastern sector. Currently an estimated $30 \mathrm{hm}^{3}\left(\times 10^{6} \mathrm{~m}^{3}\right)$ is extracted from the aquifer for irrigation and an additional $5-10 \mathrm{hm}^{3}$ for urban water supply.

\section{Climate change and recharge scenarios}

Stigter et al. (in press) provide a detailed overview of how the scenarios for $\mathrm{CC}$ and aquifer recharge were created. Three available Regional Climate Model (RCM) scenarios from the ENSEMBLES project (Van der Linden \& Mitchell, 2009) were used, using the $A 1 b C_{2}$ emission scenario. The modelled temperature $(T)$ and precipitation $(P)$ data were bias corrected using a reference (control) period of available observations, namely 1980-2010. Bias correction involved two different approaches: i) calculation of anomalies, and ii) monthly linear regressions between observed and modelled data (Stigter et al., in press).

The resulting bias-corrected data were used to obtain predictions of $\mathrm{P}$ and $\mathrm{T}$ for two future climate normal (30year) periods, 2020-2050 and 2069-2099, and subsequently to calculate recharge for these periods using two soil water budget methods: i) Thornthwaite-Mather, and ii) Penman-
Grindley (Stigter et al., in press). These methods were applied sequentially for each month, and calibrated using previous calculations of recharge (Stigter et al., 2009). The problem of underestimation of recharge, which often occurs when using a monthly time step (e.g. Dripps \& Bradbury, 2007 ), was accounted for by allotting $20 \%$ of rainfall as direct groundwater recharge before performing the remaining balance calculations.

Besides scenarios for total recharge, the impacts of global warming on crop water demand and consequently groundwater withdrawals for irrigation were also quantified, by performing simplified calculations on the evolution of the potential evapotranspiration (Stigter et al., in press). It was assumed that there is no change in crop type, growth cycle, irrigated area or irrigation efficiency.

\section{Socio-economic development scenarios}

The main goal of SED scenarios is to function as a foresight tool helping decision-makers to explore the uncertainty associated with future developments. Foresight is defined here as a multi-disciplinary approach whose goal is to help decision-makers explore the uncertainty associated with future developments, and to assess the consequences of the various strategic choices available. In this specific case we focused on agriculture and its impact on water use. The methodological approach was inspired by the emerging literature on scenario planning and participatory foresight for water resources management (Van der Helm, 2003; Hatzilacou et al., 2007). Construction of the SED scenarios, aiming at 2030 , was based on a diversity of sources of information: (i) pre-existing scenarios defined at national and European levels, (ii) statistical information describing recent trends in local agriculture, (iii) an identification of factors of change made through a specific workshop with experts and (iv) individual visions of the future expressed by farmers during interviews or in a preliminary workshop.

These scenarios were subsequently pre-tested next to the

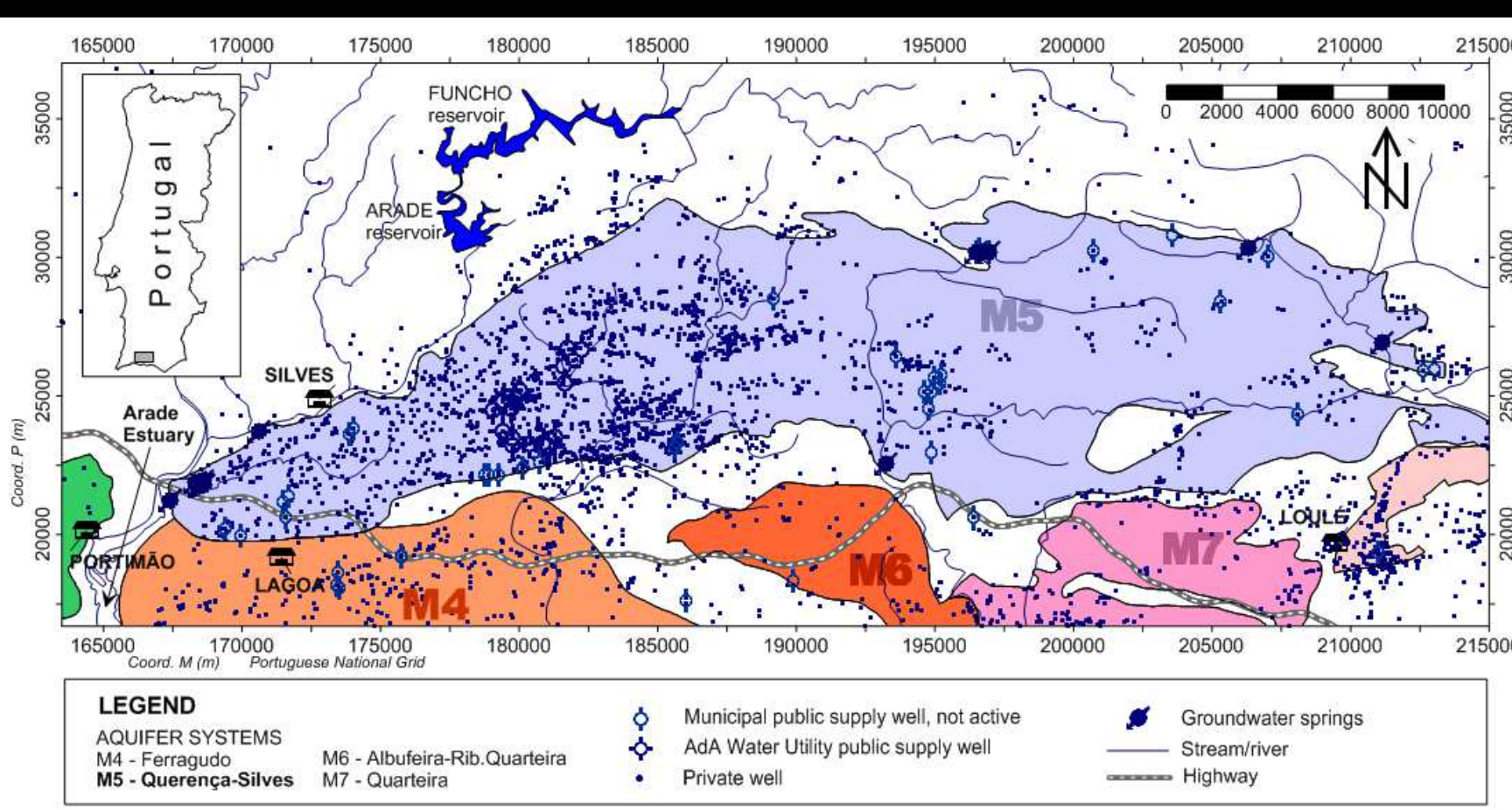

Figure 1. Location and characterisation of water use and availability in the study area. 
actors involved (namely farmers and institutional actors in the water sector). Given the high complexity of carrying out such participatory workshops, related for instance with the difficulty of envisioning the future, the understanding of SED scenarios and the lack of experience of farmers in holding such discussions, the research team took a few preparatory steps prior to the workshop. These consisted in the collection of information, through interviews and a preliminary participatory workshop, focusing on the current problems in the regional agriculture.

For the scenarios workshops, the research team had to take special care regarding the content of discussion and the information transmitted, including its format for the specific public (see Figure 2 as an example), as well as the participatory techniques employed, the style of facilitation (e.g. neutrality, creation of mutual trust), the location of the workshops and finally the composition of the groups to assure representativeness (including farmers from different geographical areas, age groups, crop types and farm size).

\section{Groundwater flow model}

Numerical simulation models for groundwater flow in the aquifer have been performed and improved over the past decade (e.g. Monteiro et al., 2006; Stigter et al., 2009; Hugman et al., 2012). Parameterisation and calibration procedures and results can be consulted in those papers. The model was calibrated for 2001-2006 and validated for 2006-2010. In a following step SED and CC scenarios were integrated in the model, in steady-state and transient simulations, to study their individual and joint impacts on water levels and discharge rates into the coastal estuary.

\section{RESULTS AND DISCUSSION}

Figure 3 presents the projected changes in rainfall $(P)$ vs. temperature (T) for 2020-2050 (2035) and 2069-2099 (2085). The effect of global warming is clear, with an average rise in $\mathrm{T}$ of 1.3 and $3.4{ }^{\circ} \mathrm{C}$ for the short-term and long-term future, respectively. Regarding $P$, the large uncertainty in short-term predictions is well reflected in the plot, with some scenarios predicting a slight increase. The ensemble mean shows a $7 \%$ decrease in $P$ for 2035 , and a $29 \%$ decrease for 2085. In the long-term future all scenarios

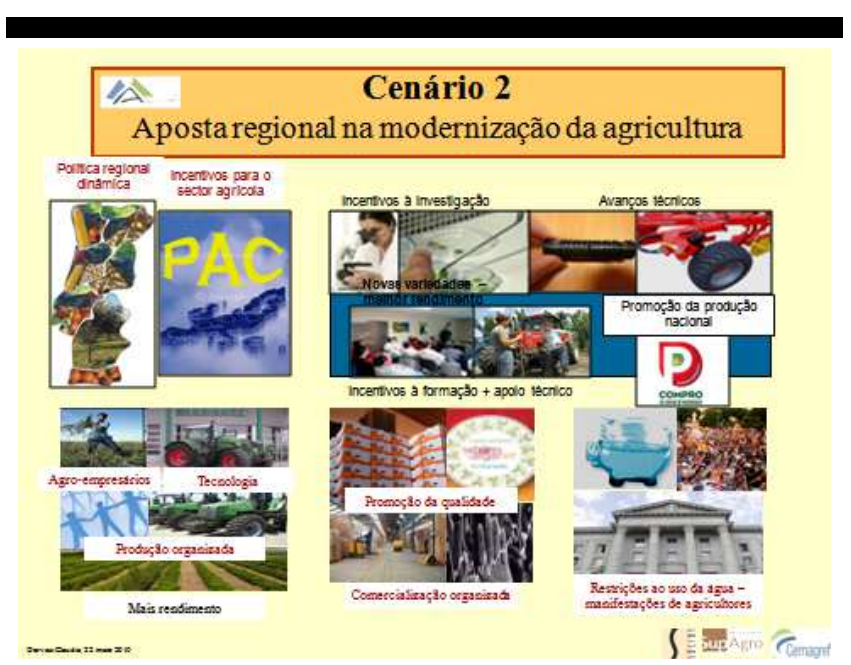

Figure 2. Illustration of poster used in workshops presenting SED scenario 2. agree on a strong reduction in $\mathrm{P}$. Both phenomena, i.e. short-term uncertainty and long-term trends in $P$, reflect themselves on the predicted evolution of aquifer recharge under $\mathrm{CC}$. Figure 4 compares the latter to the predicted impacts from the SED scenarios, described in Table 1, for 2035 and 2085. Although it may be less logical to perform the combined study on CC and SED for the distant future, the long-term predictions are believed to be illustrative for CC trends and their potential interference with SED scenarios, even though the latter were developed for 2030 .

The white symbols in Figure 4 represent the quantification of the SED scenarios, ignoring $\mathrm{CC}$. The duplication in irrigated land in SED scenario 2 (SED2) has resulted in an additional $30 \mathrm{hm}^{3}$ (million $\mathrm{m}^{3}$ ) demand for irrigation. On the contrary, SED scenario 1 (SED1) has resulted in a significant reduction in irrigated land and crop water demand (only $8 \mathrm{hm}^{3}$ ). SED scenarios 3 and 4 (SED3_4 in Figure 4) have distinct characteristics, but the corresponding changes in water demand for agriculture were considered to be small, and were set to 0 . Hence, combining CC with SED scenarios for the latter two is equivalent to considering the exclusive impact of $\mathrm{CC}$, represented by the squared symbols in the plots. For 2035 the scatter among these values is evident, with both predicted increases and decreases in recharge, and reflects uncertainty inherent in different combinations of climate model runs, bias correction and recharge calculation methods. Notwithstanding, the ensemble mean depicts an $8 \mathrm{hm}^{3}$ (around $8 \%$ ) decrease in recharge. Moreover, all but one CC scenario predict an increase in irrigation demand, solely due to higher evaporative demands. As a result, three of these scenarios plot near or beyond the border where groundwater abstractions become unsustainable, according to criteria of defined by Hugman et al. (2012), which are based on negative groundwater heads and the cessation of groundwater discharge into the estuary in the summer season, leading to seawater intrusion. In 2085 all but one $\mathrm{CC}$ scenario are located in the field of insustainability.

Interestingly, both SED3 and SED4 are among the most desired scenarios by the stakeholders in the region, but considered as unlikely. On the contrary, SED1 is considered a highly probable scenario, but least desirable by the water actors, particularly the farmers, as it represents the decline of agricultural activity. As a consequence of the large reduction in water use, none of the SED1/CC combinations plot in the critical zone (Figure 4) for 2035, and many indicate an increase in water availability. This is not the case for 2085 , due to a large predicted decrease in recharge. It must be noted that the indicated drop of $70 \%$ in irrigation demand may be excessive, since properties are expected to increase in size and in part compensate for the decline of

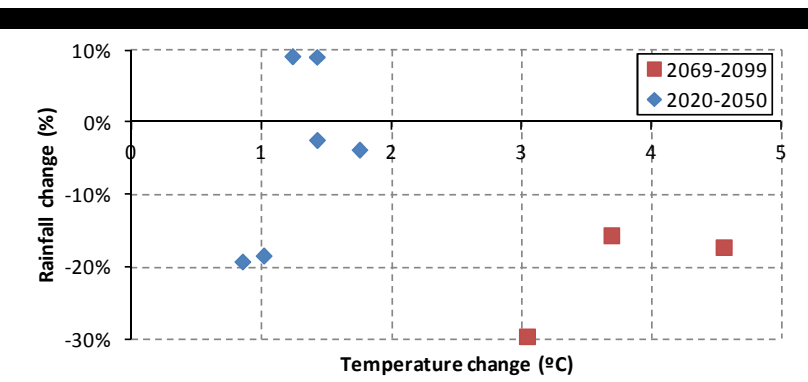

Figure 3. Predicted changes in rainfall vs. temperature, for different climate model runs and bias correction methods. 
Table 1. Description of the scenarios.

\begin{tabular}{|c|c|c|c|}
\hline $\begin{array}{l}\text { Global economic } \\
\text { context and agricultural } \\
\text { market }\end{array}$ & $\begin{array}{l}\text { Economy and } \\
\text { territory in Algarve }\end{array}$ & Agricultural sector & $\begin{array}{l}\text { Use of water } \\
\text { resources }\end{array}$ \\
\hline
\end{tabular}

$\begin{array}{ll}\text { SED1: Intensive } & \text { World economy highly } \\ \text { agriculture, } & \text { liberalized; Algarve's } \\ \text { decline of small } & \text { agriculture faces strong } \\ \text { farms } & \text { competition. }\end{array}$

Farmland decreased

Development of tourism substantially, small

(main economic sector) properties vanish. Some

contributes to decrease highly competitive farms of farmland.
Large decrease in irrigation needs; public supply stable, with slight increase in tourism sector.

\begin{tabular}{|c|c|c|c|c|}
\hline $\begin{array}{l}\text { SED2: Growth } \\
\text { and } \\
\text { modernization } \\
\text { of agriculture }\end{array}$ & $\begin{array}{l}\text { Agriculture policy transfer } \\
\text { from EU, supporting } \\
\text { agriculture in the Algarve; } \\
\text { aggressive marketing of } \\
\text { national products. }\end{array}$ & $\begin{array}{l}\text { Tourism declining due } \\
\text { to strong competition } \\
\text { from other destinations. }\end{array}$ & $\begin{array}{l}\text { Ambitious policies, strong } \\
\text { financial investments, land } \\
\text { restructuring and } \\
\text { marketing. Farms are } \\
\text { larger and more intensive. }\end{array}$ & $\begin{array}{l}\text { Water use reaches } \\
\text { levels never attained } \\
\text { before, conflicts of use } \\
\text { are frequent. }\end{array}$ \\
\hline $\begin{array}{l}\text { SED3: Dual } \\
\text { agriculture } \\
\text { competitive } \\
\text { capacity and } \\
\text { patrimony }\end{array}$ & $\begin{array}{l}\text { Two types of agriculture } \\
\text { in Europe: i) highly } \\
\text { competitive and } \\
\text { intensive; ii) subsidized } \\
\text { and dedicated to high } \\
\text { quality products (largest } \\
\text { area). }\end{array}$ & $\begin{array}{l}\text { Strong investment: } \\
\text { attract senior } \\
\text { immigration, improving } \\
\text { local economy; tourism } \\
\text { very dynamic } \\
\text { expanding to Algarve's } \\
\text { interior. }\end{array}$ & $\begin{array}{l}\text { Two types of farms: highly } \\
\text { efficient large properties } \\
\text { and small farms living of } \\
\text { subsidies, growing } \\
\text { indigenous cultures. }\end{array}$ & $\begin{array}{l}\text { Remains stable for } \\
\text { agriculture, but } \\
\text { population increase } \\
\text { has led to increase in } \\
\text { public supply }\end{array}$ \\
\hline $\begin{array}{l}\text { SED4: } \\
\text { Sustainable } \\
\text { development, } \\
\text { agriculture of } \\
\text { high } \\
\text { environmental } \\
\text { performance }\end{array}$ & $\begin{array}{l}\text { Environmental and health } \\
\text { issues have become } \\
\text { priority for agricultural } \\
\text { policies and consumer. } \\
\text { Intensive production } \\
\text { banished. }\end{array}$ & $\begin{array}{l}\text { Total restructuring of } \\
\text { agriculture in line with } \\
\text { sustainability concerns. } \\
\text { Emphasis on local } \\
\text { production. Decline in } \\
\text { international tourism. }\end{array}$ & $\begin{array}{l}\text { Use of land remains } \\
\text { similar, form of production } \\
\text { becomes more } \\
\text { sustainable, possible } \\
\text { thanks to state's } \\
\text { investment in qualification } \\
\text { of young farmers. }\end{array}$ & $\begin{array}{l}\text { Water consumption } \\
\text { remains stable. Highly } \\
\text { efficient irrigation is } \\
\text { used. }\end{array}$ \\
\hline
\end{tabular}

small areas. On the other hand, farming techniques are considered to improve, increasing water use efficiency.

The combination of SED2, where a large expansion of irrigated land is expected, with the CC scenarios, results in the largest predicted increase in pressure on the available water resources, despite the persisting scatter in the data. In fact, without considering CC the SED2 scenario already plots very near the limit of insustainability. The combination with the ensemble mean CC results causes a shift in the diagram beyond the limit of sustainable aquifer exploitation. Most of the combinations are located far beyond this limit. The predicted increase in crop water demand resulting from warming is also most pronounced in this scenario. For 2085 the referred impacts are further enhanced.

Figure 5 shows the predicted lowering of average yearly groundwater levels for 2035 . It is interesting to observe the pronounced difference between the impacts of the SED2 scenario with and without $\mathrm{CC}$, in the western sector of the aquifer. When CC is ignored, the decrease in groundwater head in the east is relatively modest and constant, between 4 and $6 \mathrm{~m}$, resulting from the increased withdrawals that are largely concentrated in the west (Figure 1). A reduction in recharge however affects the entire area and particularly the eastern area, where recharge is highest, and therefore results in much more pronounced drops in groundwater level, between 10 and $20 \mathrm{~m}$, and even up to $30 \mathrm{~m}$ in a smaller area in the northeast. This can have significant consequences for farmers living in this area and also for groundwater dependent ecosystems that exist in the region.

Besides average changes, it is important to look at seasonal changes and the occurrence of extreme events. Figure 6 show transient simulations of groundwater discharge into the estuary for two CC scenarios, one of
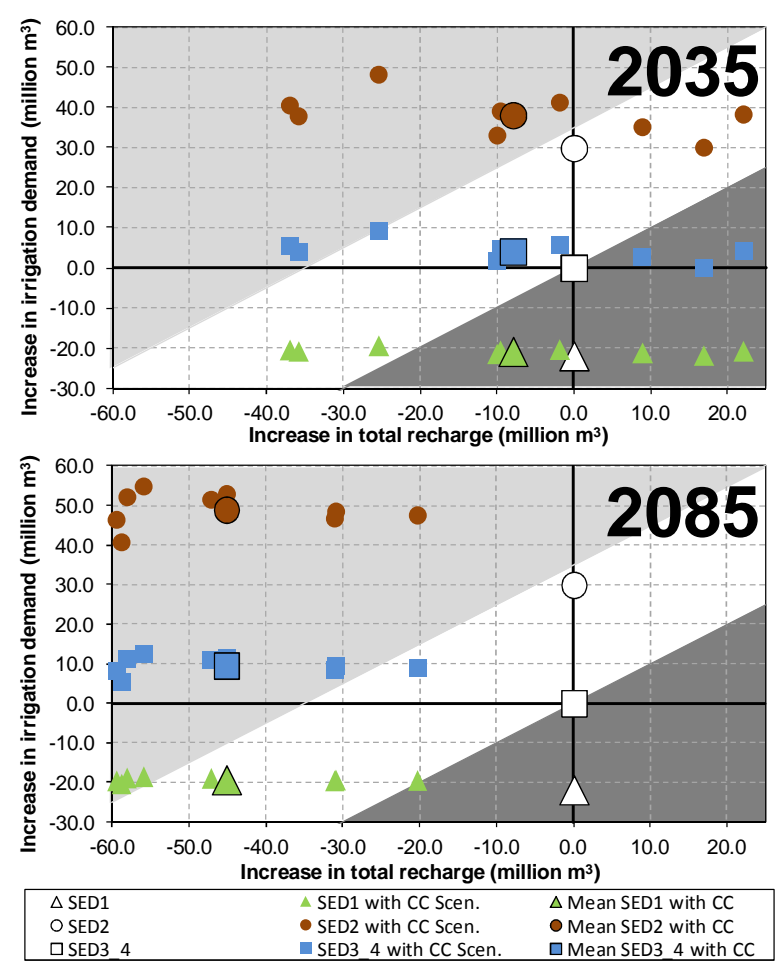

Figure 4. Increase in irrigation demand and total recharge for 2035 and 2085, for SED and CC scenarios; lightshaded area indicates critical state beyond sustainability (Hugman et al., 2012); dark-shaded area represents an increase in water availability with respect to present state. 


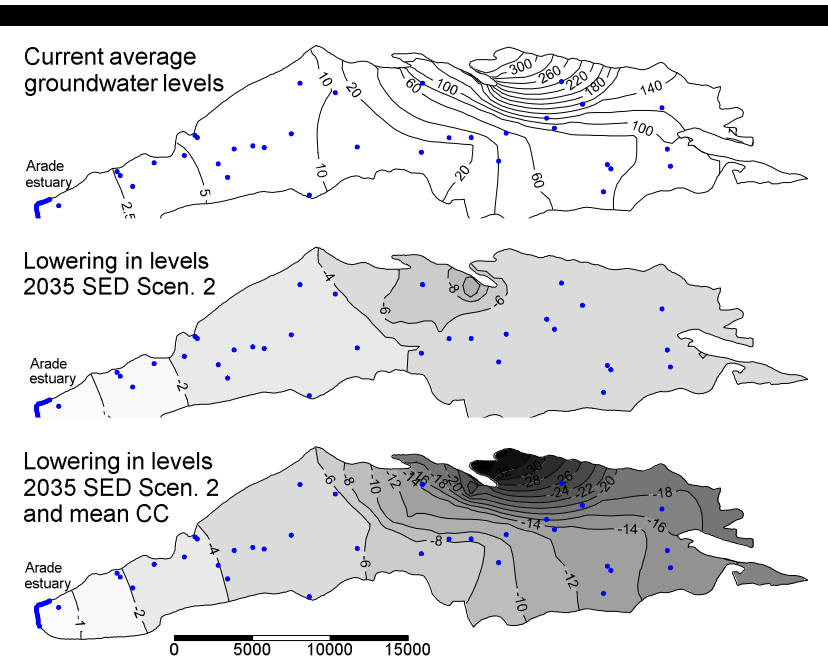

Figure 5. Average groundwater levels ( $m$ above mean sea level) in the aquifer: current situation (top), predicted lowering in 2035 with SED2 (middle), and lowering due to its combination with mean CC (bottom); blue dots are monitoring wells, blue line boundary condition at estuary.

them combined with SED2. Despite the difference in average levels, both CC scenarios show pronounced seasonal and interannual variations, with the alternation of dry periods (zero or negative outflow, indicating seawater intrusion) and wet extremes (marked by high discharge rates). The increase in frequency of these phenomena is discussed by Stigter et al. (in press). The combination of the more pessimistic CC scenario with SED scenario 2 reveals high rates of seawater intrusion in many years and almost continuously towards the end of the century.

It is clear from the foregoing that, despite existing uncertainties, the combination of SED scenario 2 and CC is most likely not sustainable. In other words, agriculture as a driver of Algarve's development, and the reinforcement of policies conducting to it, may only be adequate if alternative water sources are found.

\section{CONCLUSION}

The integration of SED scenarios, designed and discussed in a participatory manner, with $C C$ scenarios provides a more complete picture of possible future changes in water resources, then when based exclusively on climate models. Our results reveal that $\mathrm{CC}$ in the region will dynamically interact with economic factors and may force a restructuring of ways of living. Unfortunately much uncertainty remains regarding the projected paths of future climate, particularly on regional scales and short term horizons. Notwithstanding, the more frequent occurrence of extreme events will encourage no-regret strategies such as water saving techniques and the search for alternative water sources. We believe that "mixed-methods" approach, combining qualitative and quantitative methodologies from both the social and natural sciences, can provide the best answers. Hence exercises such as this one of envisioning different paths for the SED of the region are needed for citizens and policy makers to take action.

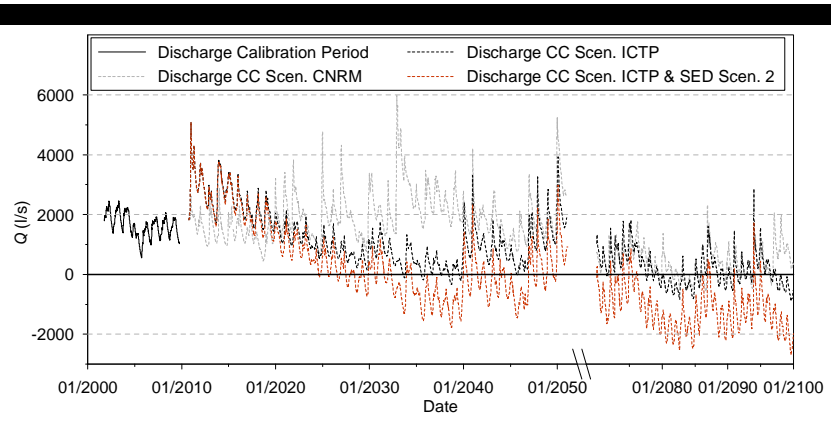

Figure 6. Evolution of groundwater discharge into the estuary for two CC scenarios, one combined with SED2.

\section{ACKNOWLEDGEMENT}

The research that supports this paper was performed within the scope of the CLIMWAT and AQUIMED projects funded under the CIRCLE-2 ERA-Net. The authors wish to acknowledge the Fundação para a Ciência e a Tecnologia for supporting this network. The collaboration of Claudia Gervasi was crucial for the development of SED scenarios.

\section{LITERATURE CITED}

Brouyère, S., et al., 2004. Climate change impacts on groundwater resources: modelled deficits in a chalky aquifer, Geer basin, Belgium. Hydrogeology Journal, 12, 123-134.

Candela, L., et al., 2009. Impact assessment of combined climate and management scenarios on groundwater resources and associated wetland, Majorca, Spain. Journal of Hydrology, 376, 510-527.

Dripps, W.R. \& Bradbury. K.R., 2007. A simple daily soil-water balance model for estimating the spatial and temporal distribution of groundwater recharge in temperate humid areas. Hydrogeology Journal, 15, 433-444.

Faysse, N., et al., In press. Participatory analysis for adaptation to climate change in Mediterranean agricultural systems: making use of possible choices in process design, Regional Environmental Change, doi: 10.1007/s10113-012-0362-x.

Giorgi, F., 2006. Climate change hot-spots. Geophysical Research Letters, 33, L08707.

Hatzilacou, D., et al., 2007. Scenario workshops: A useful method for participatory water resources planning? Water Resources Research, 43, W06414.

Hugman, R., et al., 2012. Influence of aquifer properties and the spatial and temporal distribution of recharge and abstraction on sustainable yields in semi-arid regions. Hydrological Processes, 26, 2791-2801.

Jackson, C.R., et al., 2011. Modelling the effects of climate change and its uncertainty on UK Chalk groundwater resources from an ensemble of global climate model projections. Journal of Hydrology, 399, 12-28.

Monteiro, J.P., et al., 2006. Inverse Calibration of a Regional Flow Model for the Querença-Silves Aquifer System, Algarve-Portugal. Integrated Water Resources Management and Challenges of the Sustainable Development, IAH Marrakech, pp 44.

Nakićenović, N. \& Swart, R. (eds), 2000. Special Report on Emissions Scenarios: A special report of Working Group III of the Intergovernmental Panel on Climate Change, Cambridge University Press, Cambridge, UK.

Roncoli, C., 2006. Ethnographic and participatory approaches to research on farmers' responses to climate predictions. Climate Research, 33, 81-99.

Stigter, T.Y., et al., 2009. Screening of sustainable groundwater sources for integration into a regional drought-prone water supply system. Hydrology and Earth System Sciences, 13, 1-15. 
Stigter, T.Y., et al., In press. Comparative assessment of climate change impacts on coastal groundwater resources and dependent ecosystems in the Mediterranean. Regional Environmental Change, doi: 10.1007/s10113-012-0377-3.

UNESCO, 2010. World Social Science Report: Knowledge Divides, UNESCO Publishing. http://www.unesco.org/new/en/social-andhuman-sciences/resources/reports/world-social-science-report/.

Van der Helm, R., 2003. Challenging futures studies to enhance EU's participatory river basin management. Physics and Chemistry of the Earth, 28, 563-570.

Van Der Linden, P. \& Mitchell, J.F.B. (eds), 2009. ENSEMBLES: Climate Change and its Impacts: Summary of research and results from the ENSEMBLES project. Met Office Hadley Ctr, Exeter, UK.

Varanda, M. \& Bento, S., 2012. Alterações climáticas e circulação do saber entre ciência e prática: uma via de um sentido, dois sentidos ou um beco sem saída. $2^{\mathrm{a}}$ Jornada Ciêntifica da Rede MUSSI "Redes e processos info-comunicacionais: mediações, memórias, apropriações", ANAIS 2012. ISBN: 978-85-85471-18-4. 